\title{
EXPLORATION AND EXPLOITATION OF SHALLON FRESH WATER LAYERS IN COASTAL AREAS
}

\author{
J.A. VAN 'T LEVEN \\ (Institute for Land and Water Management Research, \\ Wageningen, the Netherlands)
}

\section{SUMMARY}

In the Delta area it is possible to predict from detailed soil maps the presence of fresh water in the subsoil. The usable quantity present must be determined either by exploration borings or by the geo-electrical method.

There is a possibility to exploit shallow fresh water layers by pumping fresh- and salt water separately, but simultaneously, from different depths. To diminish the danger of salinization of the open polder waters, the rate of pumping salt water will have to be kept at a minimum.

The salt water boundary, slightly raised as a result of the different rate of pumping fresh- and salt water, is pushed down to its original depth by the higher discharge rate of the ground-water and by pumping during autumn and winter salt water only.

An investigation with the aid of a laboratory model, giving the possibility to work with other profiles, transmissibilities, discharge- and pumping rates and different depths of fresh water layers, will take place.

It is the aim to learn the minimum depth of usable water layers, the best ratio between the rates of fresh- and salt water to be pumped, the influence of the permeability and other factors of the soil, and the derivation of a formula for the streaming of water with a specific weight changing with depth.

\section{RÉSUMÉ}

\section{Exploration et exploitation de fines couches d'eau douce dans les regions littorales}

Les Pays-Bas se composent d'une partie basse et d'une partie plus élevée. La partie basse du pays contient de l'eau douce dans le sol jusqu'à une profondeur relativement faible seulement. C'est que ces sols ont été déposés par la mer et les circonstances pendant la sédimentation et celles du drainage souterrain étaient telles qu'ils n'ont pas été dessalés plus profondement.

Une grande variété d'épaisseurs de couches d'eau douce est présente dans le sud-ouest de la région du Delta. L'eau douce n'atteint parfois qu'une profondeur

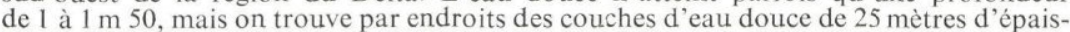
seur ou davantage. La topographie du terrain et une carte pédologique permettent de prédire la présence ou l'absence de couches d'eau douce.

Certaines parties de la région du Delta ont un grand besoin d'eau douce pour l'irrigation, surtout dans l'horticulture. Cette eau ne peut être amenée d'ailleurs, de sorte qu'il faut avoir recours à l'eau souterraine de la région, eau qui doit en outre être de bonne qualité.

Par la prise de l'eau douce seule, la limite des eaux salées monte parfois à la hauteur du filtre de pompe, de sorte qu'il se produit un mélange d'eau douce et d'eau salée. $\mathrm{Si}$ les proportions sont défavorables, l'emploi de cette eau — pour l'irrigation par aspersion par exemple - produira des dégâts. La prise simultanée d'eau douce et d'eau salée du sol fait monter la limite d'eau salée jusqu'à une plus faible hauteur. Cette hauteur dépend, entre autres facteurs, de la proportion de prélèvement d'eau douce et d'eau salée. Un tel essai de pompage a été effectué à Lewedorp dans l'île de Zuid-Beveland dans une couche d'eau douce épaisse de 16 mètres environ. Par heure, on a pris ici $10 \mathrm{~m}^{3}$ d'eau douce et $4 \mathrm{~m}^{3}$ d'eau salée. Et en effet la limite d'eau salée monta moins qu'en cas de pompage exclusif d'eau douce. En pompant uniquement de l'eau salée, on a ramené artificiellement la limite d'eau salée à son niveau originel. 


\section{INTRODUCTION}

The Netherlands can roughly be divided into a peatmoor and marine clay district, lying at or below sea level, and an alluvial sand district somewhat higher above sea level.

In the higher part of the country fresh water of good quality is to be found down to depths of 200 meters and more, that can be used, in some cases after a purification process, for all purposes as drinking water, water for industry, for sprinkling, sub-irrigation, etc. In the lower lying part of the country fresh ground-water is more difficult to obtain, except in the narrow coastal area where the fresh water body extends to depths of approximately 100 meters under the dunes. In the Delta region (fig. 1), for the greater part located in the province of Zeeland,where the soil consists

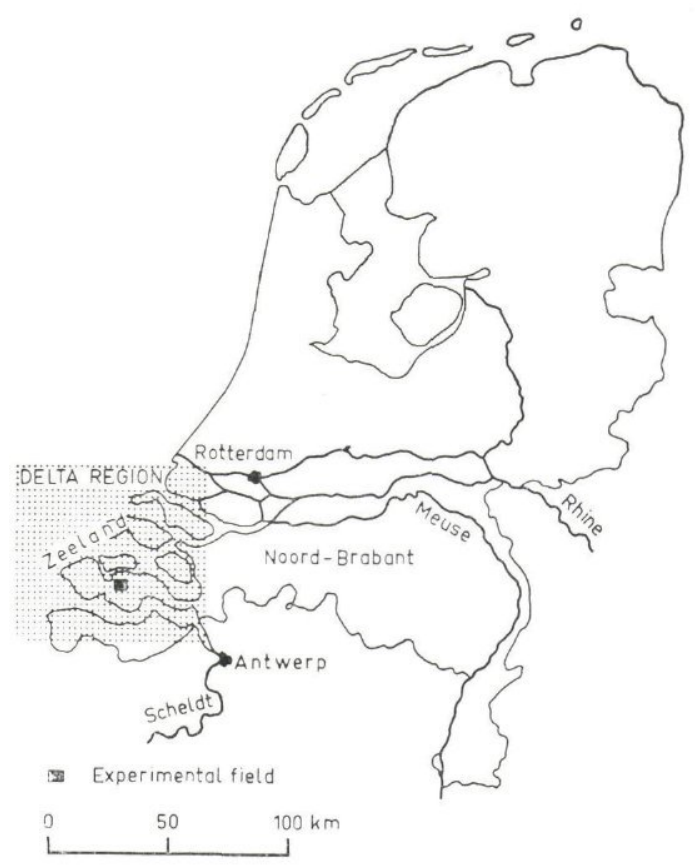

Fig. 1 - Situation map.

of marine sediments and where large estuaries penetrate deeply behind the general coastline, hardly any fresh ground-water is available.

The need for supplemental water is locally large in this region, however, since only a small amount of soil moisture is available during the growing season. A supply of fresh water from the neighbouring province of Noord-Brabant will give prohibitive costs per water-supplied acre. It is necessary therefore to exploit any small quantities of fresh water present in the subsoil.

By means of borings, shallow fresh water layers were mapped and the composition and litho-stratification of the subsoil was determined by means of soil samples. Pumping experiments were then carried out, both by pumping the fresh water layers alone and by pumping separately, but simultaneously, the fresh water layer and the 
saline water underneath this layer. The quantities of water pumped were measured and the effect of the pumping on the depth of the fresh-salt water boundary and the salinization of the subsoil was observed.

\section{Exploration}

The genesis of the polder soils in the Delta area is as follows. During one of the regression periods of the North Sea, the dune-coast was closed except for some small gaps through which the rivers Rhine, Meuse and Scheldt had their outlet to the sea. Behind the dune coast extensive marshes were present. During transgression at a later stage, the dunes were partly destroyed, while the sea made creeks in the marshy areas. Later, these creeks were filled up with sandy-and clayey soils, while on the remaining peat soils young marine clay was deposited. Because of differences in compaction of the various sediments, a relief inversion took place with the result that today the sandy creeks are situated at a higher level than the clay-peat soils.

It is typical for the Delta area, therefore, that there is a relation between topografic height, the permeability of the soil profile and the presence of fresh water. When, for example, the field is high, the soil profile will be sandy, therefore the permeability is high and fresh water is present. When on the contrary the field is lying low, the soil profile will consist of clay and peat, the permeability will be low and no fresh water layer will be present.

The above given sequence of events is true for the old polders as well as for the new polders, diked-in in the recent sea-arms. Where peat is eroded and replaced by sand, the chance of finding a fresh water body under favourable hydraulic circumstances is a good one. The soil map, completed with borings or electrical resistance measurements, can therefore be a guide to predict the possibility of finding fresh- or salt water.

For the location of the field experiments an area was taken near the village of Lewedorp in the polder Nieuwe Kraayert on the island of Zuid-Beveland.

A detailed exploration of the subsoil was there carried out by means of bailer borings from which disturbed samples were taken from various depths. Also taken were ground-water samples from various depths from which the salt content was determined in the laboratory. From these samples it was possible to calculate:

$$
\begin{aligned}
& C=\frac{1000 \times B}{A} \quad \text { where } \mathrm{C}=\begin{array}{c}
\text { concentration } \\
\text { solution }
\end{array} \text { of } \mathrm{NaCl} \text { in the soil } \\
& A=\text { moisture content in grams per } 100 \text { grams } \\
& \text { of soil on a dry matter basis } \\
& B=\mathrm{NaCl} \text { content of the soil per } 100 \text { grams } \\
& \text { of soil on a dry matter basis. }
\end{aligned}
$$

The sediments of this area were deposited by the North Sea and partly by the river Scheldt during the Holocene. The Holocene river Scheldt was flowing from South to North while the present course is more towards the South in E-W direction. As can be seen from fig. 2 and 3 the Holocene riverbed crossed the polder Nieuwe Kraayert.

The experimental field near the village of Lewedorp has the following soil profile:

$0-0.40 \mathrm{~m}$ sandy clay $20 \%<16 \mu$

$0.40-30.0 \mathrm{~m}$ sand

$30.0-32.0 \mathrm{~m}$ clay, $60 \%<16 \mu$, impermeable

$32.0-36.0 \mathrm{~m}$ sand 




Fig. 2 - Schematic cross-section of the experimental field in the polder Nieuwe Kraaijert. At the right the fresh-salt water boundary is given. Situations like this occur all over the Delta region.

Where the banks of the old river were located another clay horizon was left in the profile at a depth of 5 to 8 meters below soil surface.

The surface of this part of the polder lies approximately 1 to 1.5 meters above Ordnance Datum. The water level in the ditches and the ground-water level is maintained during summer at approximately Ordnance Datum, so approximately $1.5 \mathrm{~m}$ below soil surface. In the surrounding area to the $N, W$ and $E$, the polder water levels lie deeper namely between 1.90 and $1.25 \mathrm{~m}$ below Ordnance Datum.

The fresh water body is present in the sandy soil down to the shallow clay layer where the old river banks are present; in the middle of the old river course to a greater depth in the sandy layers.

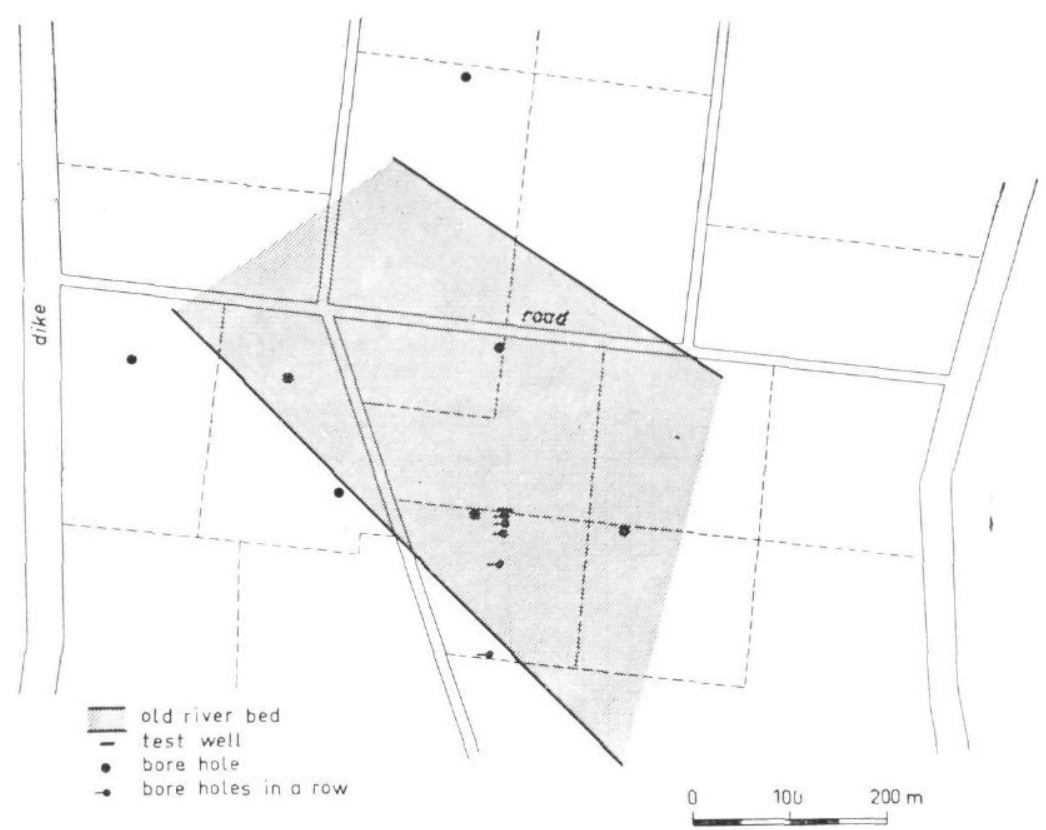

Fig. 3 - Map of the experimental area. 


\section{FIELD EXPERIMENTS}

To measure, during and after the field tests, the variations in the ground-water level and the changing of the fresh-salt water boundary, bore holes, in which piezometers were installed at depths of $4.00,5.50,7.00,8.50,10.00,11.50,13.00,14.50$ and $16.00 \mathrm{~m}$ below soil surface, were made surrounding the test well (fig. 3 ). To determine the fluctuations of the salt water boundary in greater detail, 5 bore holes were placed in a row at distances of respectively $0.5,5,15,50$ and $150 \mathrm{~m}$ from the well. Here also piezometers were placed at depths, ranging from 4.00 to $16.00 \mathrm{~m}$.

\subsection{Pumping fresh water only}

In 1958 only fresh water was pumped, although it was known that pumping large quantities fresh water will give a rise in the underlying salt water boundary, making it impossible to exploit the shallow fresh layer further. It was necessary, however, to determine the fluctuation of the salt water boundary with this method to be able to compare it with the method of pumping fresh- and salt water separately, but simultaneously. From the 21 st of August to the 22 nd of October a total amount of $10465 \mathrm{~m}^{3}$ was pumped from a depth of 9 to $14 \mathrm{~m}$ below surface in 1024 hours at a rate of $10 \mathrm{~m}^{3}$ per hour. In fig. 4 the depth of the $1000 \mathrm{mg} \mathrm{Cl}^{-}$-l-boundary before

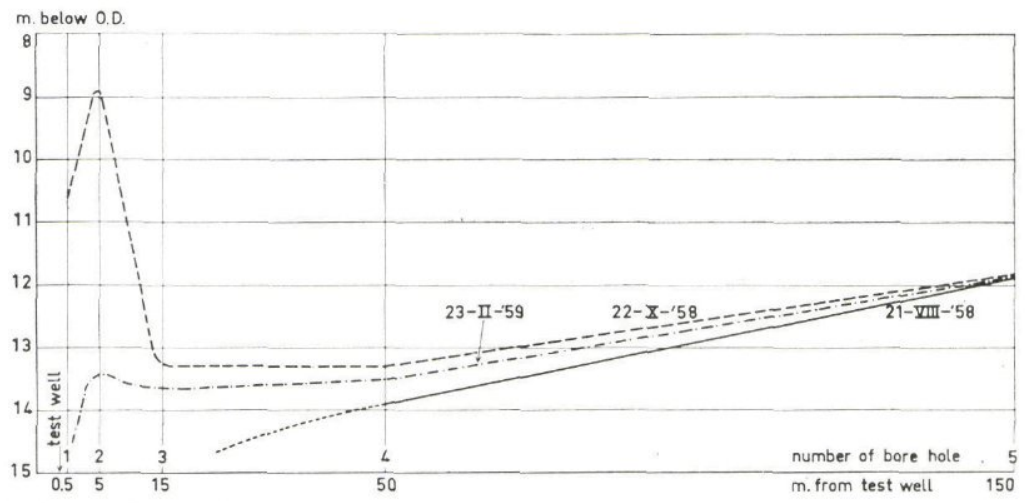

Fig. 4 - Rising of the $1000 \mathrm{mg} \mathrm{C1-/1}$ boundary when pumping fresh water only, from a depth of 2.5 to $7.5 \mathrm{~m}$ below Ordnance Datum and a subsequent drop in the rest period. Full line $=$ before pumping; broken line = after pumping;
dash-dot $=$ after the rest period.

and at the end of the test, and after a rest period is given. As can be seen, the $1000 \mathrm{mg}$ $\mathrm{Cl}$-line was situated deeper than $15 \mathrm{~m}$-Ordnance Datum (16.50 m-soil surface) in the boreholes 1, 2 and 3. During pumping the salt level was rising sharply up to $9 \mathrm{~m}$ Ordnance Datum in the vicinity of the test well, at which moment the test was stopped.

It was expected that a regular salt water cone would develop. The drop of the $1000 \mathrm{mg}$ line from bore hole 2 to 1 cannot be accorded for, although there is a possibility that this is due to differences in transmissibility of the soil.

Apart from this irregularity, the top of the cone did have a small diameter of approximately 10 meters. The base had a diameter of approximately $30 \mathrm{~m}$ at a depth of $13 \mathrm{~m}$-Ordnance Datum. During the rest period the salt boundary did drop and reached, although precipitation was lower than normal, in the spring of 1958 a depth of $13.50 \mathrm{~m}$-Ordnance Datum in bore hole 2. The original depth was not reached, 
however. To start the following test as near as possible with the salt water boundary at its original depth, in the spring of 1959 only salt water was pumped.

\subsection{Pumping salt water only}

In the period March 24th to May 15th, 1959, salt water was pumped from a depth of 18.5 to $24.5 \mathrm{~m}$-Ordnance Datum with a rate of 2 to $3 \mathrm{~m}^{3}$ per hour to a total of $2020 \mathrm{~m}^{3}$. As can be seen from fig. 5 the $1000 \mathrm{mg} \mathrm{Cl}^{-} / 1$ boundary dropped to a level only somewhat above the original level.

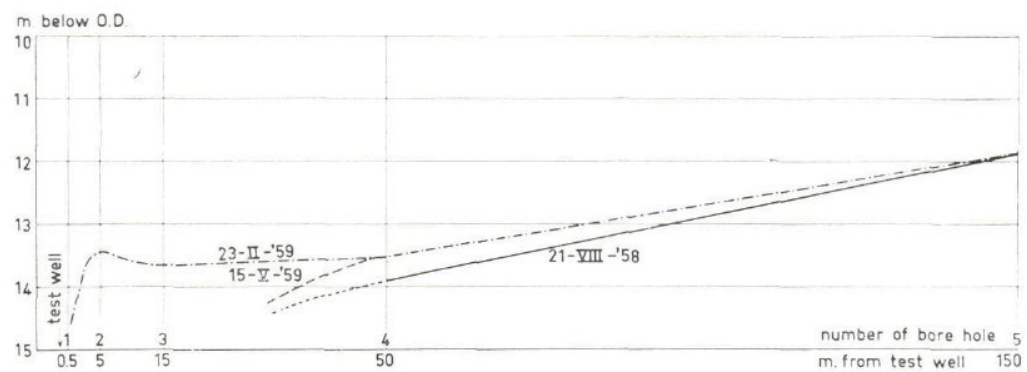

Fig. 5 - Drop of the $1000 \mathrm{mg} \mathrm{Cl}-/ 1$ boundary in the subsequent pumping of salt water only, from a depth of 18.5 to $24.5 \mathrm{~m}$ below Ordnance Datum. Dash-dot = before pumping salt water (see fig. 4); broken line = after pumping salt water; full line $=$ original depth of the boundary.

\subsection{Pumping fresh-and salt water simultaneously}

To prevent the salt boundary from rising and in this way exhausting the fresh water supply at the place of pumping, an experiment was made with pumping freshand salt water simultaneously, but separately. In the test well two filters were installed, one at a depth of 2.5 to $7.5 \mathrm{~m}$-Ordnance Datum in the fresh water zone, the other at 18.5 to $24.5 \mathrm{~m}$ - Ordnance Datum in the underlying salt water.

The success of this method was already known when pumping from relatively deep layers, but the possibility to apply the method to fresh water layers of shallow depth had not been made certain.

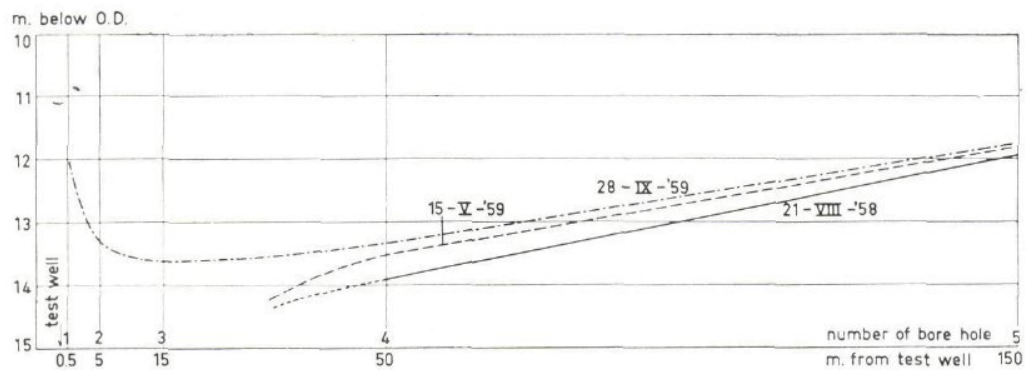

Fig. 6 - Subsequent pumping fresh- and salt water separately, but simultaneously, from depths of respectively 2.5 to 7.5 and 14.5 to $23.5 \mathrm{~m}$ below Ordnance Datum. Depth of the $1000 \mathrm{mg} \mathrm{Cl}-/ 1$ boundary: broken line = before pumping both fresh- and salt water (see fig. 5); dash-dot = after the pumping; full line = original depth of the boundary. 
From May 15th to September 28th, 1959, water was pumped, with interruptions, at a rate of 4 and $10 \mathrm{~m}^{3} /$ hour for the salt- and fresh water respectively. The total amount pumped was $12722 \mathrm{~m}^{3}$ for the fresh- and $4290 \mathrm{~m}^{3}$ for the salt water.

From fig. 6 it is evident that the $1000 \mathrm{mg}$ line was raised, but less than in the case of pumping fresh water alone. Theoretically it is possible to keep the fresh-salt water boundary fixed at a certain level, when pumping fresh- and salt water at the same rate. One of the reasons this was not done, is the keeping of the salt content of the open polder waters as low as possible. High salt contents there during summer would be dangerous for the windbreaks around the orchards, present in this part of the country, and would prevent other landowners to use the water for agricultural purposes, as the discharge from the polder during the growing season is small. To push the salt water boundary back to its original depth, for a second time only salt water was pumped during autumn. In that time of the year the polder system is quickly cleaned, as a higher discharge rate can be maintained.

\subsection{Second period of pumping only salt water}

Only salt water was pumped from the 28th of September to the 5 th of November, 1959 , from a depth of 15 to $25 \mathrm{~m}$-Ordnance Datum, a rate of $4 \mathrm{~m}^{3} /$ hour and totalling $3044 \mathrm{~m}^{3}$. In fig. 7 the boundary of $1000 \mathrm{mg} \mathrm{Cl}^{-}$is given for various dates during this

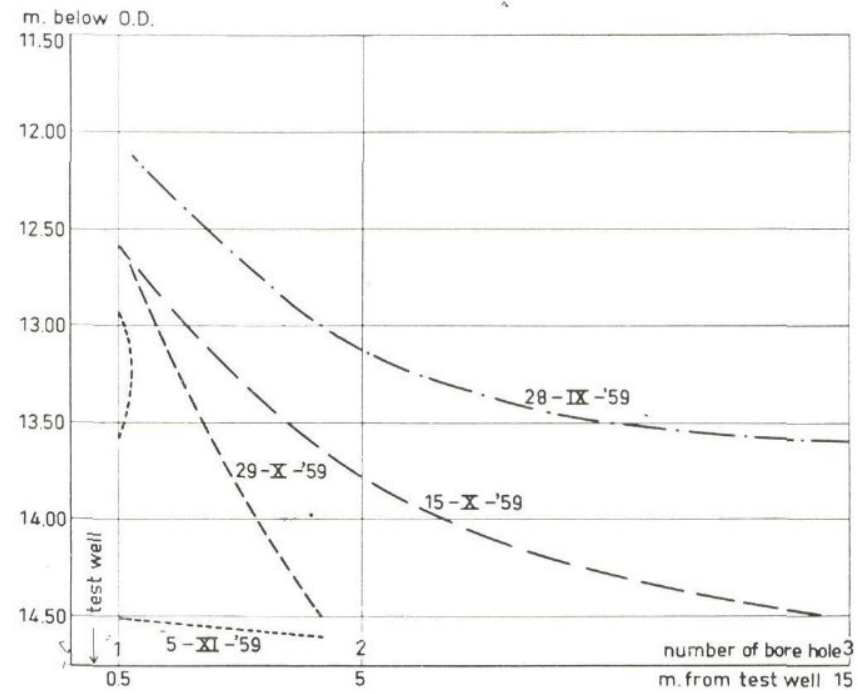

Fig. 7 - Subsequent pumping of salt water only. Drop of the $1000 \mathrm{mg} \mathrm{C1-/1}$ boundary in the neighbourhood of the test well during the pumping. Dash-dot $=$ before pumping salt water (see fig. 6).

pumping. It is clear that the salt cone shrank more and more. On the 5th of November the salt boundary was lying below $14.5 \mathrm{~m}$-Ordnance Datum, slightly above the original position. At a depth of $13.5 \mathrm{~m}$-Ordnance Datum, a small salt water bubble did remain. 